Tropical Journal of Pharmaceutical Research July 2018; 17 (7): 1301-1307

ISSN: $1596-5996$ (print); 1596-9827 (electronic)

(C) Pharmacotherapy Group, Faculty of Pharmacy, University of Benin, Benin City, 300001 Nigeria.

Available online at http://www.tjpr.org

Original Research Article

http://dx.doi.org/10.4314/tjpr.v17i7.11

\title{
Phytochemical screening, antioxidant, antiulcer and toxicity studies on Desmodium adscendens (Sw) DC Fabaceae leaf and stem
}

\author{
Gloria A Ayoola, Samuel O Eze, Oluwatosin O Johnson*, David K Adeyemi \\ Department of Pharmaceutical Chemistry, Faculty of Pharmacy. University of Lagos, Lagos, Nigeria
}

${ }^{*}$ For correspondence: Email: tosyn.villa@gmail.com; Tel: +234-8033708829

Sent for review: 24 February 2018

Revised accepted: 21 June 2018

\begin{abstract}
Purpose: To assess the phytochemical profile, toxicity, as well as the antioxidant, and antiulcer activities of the methanol extracts of Desmodium adscendens stem and leaf.

Methods: Maceration procedure was employed in the preparation of the methanol extracts. Phytochemical characterization of the extracts was carried out according to standard methods. In vitro antioxidant activity was evaluated using 2, 2-diphenyl-1-picryhyldrazy (DPPH I) and ferric reducing antioxidant power assay (FRAP). Antiulcer activity was investigated using ethanol-induced ulcer model, while toxicity was assessed by observing the mice for mortality.

Results: Phytochemical analysis indicate the presence of glycosides, alkaloids, tannins, flavonoids, and saponins in the stem and leaf. Methanol extracts of the plant exhibited antioxidant activity, with DPPH assay results showing median inhibitory concentration (IC $\left.C_{50}\right)$ of 87.59 (leaf), 108.87 (stem), 28.52 (alpha-tocopherol), and $5.05 \mu \mathrm{g} / \mathrm{mL}$ (ascorbic acid). The FRAP assay results for the stem and leaf extracts were 1483 and $1953 \mu \mathrm{M} \mathrm{Fe} e^{2+} / g$ dry plant, respectively, while for ascorbic acid it was 3463 $\mu \mathrm{MFe}^{2+} / \mathrm{g}$. The extracts showed significant antiulcer activity, with 14.27 and $15.18 \%$ ulceration inhibition for the leaf extract, and 12.31 and $13.36 \%$ for the stem extract at administered doses of 100 and 200 $\mathrm{mg} / \mathrm{kg}$, respectively. Cimetidine and omeprazole (standards) showed ulceration inhibition of 5.53, and $8.26 \%$ at 5.7 and $0.57 \mathrm{mg} / \mathrm{kg}$ doses, respectively.

Conclusion: The methanol extracts of Desmodium adscendens stem and leaf offer significant protective activity against ethanol-induced gastric ulceration in rats, and the activity may be related to their antioxidant effect.
\end{abstract}

Keywords: Antioxidant, Antiulcer, Toxicity, Desmodium adscendens

\begin{abstract}
This is an Open Access article that uses a funding model which does not charge readers or their institutions for access and distributed under the terms of the Creative Commons Attribution License (http://creativecommons.org/licenses/by/4.0) and the Budapest Open Access Initiative (http://www.budapestopenaccessinitiative.org/read), which permit unrestricted use, distribution, and reproduction in any medium, provided the original work is properly credited.

Tropical Journal of Pharmaceutical Research is indexed by Science Citation Index (SciSearch), Scopus, International Pharmaceutical Abstract, Chemical Abstracts, Embase, Index Copernicus, EBSCO, African Index Medicus, JournalSeek, Journal Citation Reports/Science Edition, Directory of Open Access Journals (DOAJ), African Journal Online, Bioline International, Open-J-Gate and Pharmacy Abstracts
\end{abstract}

\section{INTRODUCTION}

Desmodium adscendens (Family Fabaceae) is a climbing woody stem plant which grows in an uncultivated land on the West Coastal region of Africa. The species of Desmodium adscendens
(D. adscendens) is frequently found in Nigeria, Cameroon, Zimbabwe, and tropical America. It is a sole runway hedge, preferring damp locations and it is found in forest areas and on the border of savannas [1]. 
Ethnomedical studies on $D$. adscendens in India showed a broad spectrum of activity which includes antileishmanial, antioxidant, immunomodulatory, antiulcer, cardio-protective, antidiabetic, antiamnesia, antiviral, and hepatoprotective. [2]. Five phenolic compounds identified as caffeic acid, quercetin, $p$-coumaric acid, epicatechin, and rutin have been isolated and characterized from Desmodium adscendens leaves.[3]. Also, compounds that have been isolated from the leaf include phenylethylamines, indole-3-alkyl amines, tetrahydroiso-quinolones, and triterpenoid saponins [4]. The major compounds reported in the volatile oil of the leaves were phytone (14.72\%), caryophyllene oxide $(11.32 \%)$, esdesma $(7.41 \%)$, geraniol (5.42\%), linalool (5.33\%), palmitic acid (5.06 $\%)$, a-caryophyllene (4.76\%), scytalone (3.83 $\%), \beta$-ionone (3.47 \%), 2,2-dimethyl-hexanale $(3.37 \%)$, pelargonaldehyde (3.26 \%), hyperforine $(3.27 \%)$, 2-pentyl furan (2.71), oleic acid (2.68 \%), and 4- azidoheptane (2.02\%) [5].A literature research on the safety of $D$. adscendens extracts on renal, and hepatocytes cells in addition tothe protection against oxidative stress had been investigated. The report had shown that the concentrations of $D$. adscendens ( 1 and $10 \mathrm{mg} / \mathrm{ml}$ ) were safe for HEPG2 and LLCPK1 and also offers protection against oxidative stress in LLC-PK1 cells [6]. D. adscendens leaf are largely combination of flavonoids with a total polyphenol of $11.1 \mathrm{mg}$ of gallic acid equivalent $(\mathrm{GAE}) / \mathrm{g}$ dry weight $(\mathrm{dw}), 12.8 \mathrm{mg}$ of catechin equivalent $(\mathrm{CE}) / \mathrm{g} \mathrm{dw}$, while the total tannin and anthocyanin compounds were $0.39 \mathrm{mg} \mathrm{CE} / \mathrm{g} \mathrm{dw}$ and $0.0182 \mathrm{mg} \mathrm{CgE/g} \mathrm{dw}$ respectively [4]. Although Desmodium adscendens plant has gained popularity in ethnomedical uses as an antiulcer agent in Nigerian traditional medicine, there has been no empirical evidence of the antiulcer activity. As a result, the current research was focused on evaluating the gastroprotective effect of the methanol extracts of $D$. adscendens stem and leaf on ethanolinduced gastric ulceration, and also the antioxidant activity.

\section{EXPERIMENTAL}

DPPH (2, 2-diphenyl-1-picrylhydrazyl), Ferric 2,4,6-tripyridyl-s-triazine (Fe III TPTZ), Iron(III)chloride hexahydrate $\left(\mathrm{FeCl}_{3} \cdot 6 \mathrm{H}_{2} \mathrm{O}\right)$, rutin and gallic acid were ordered from Sigma-Aldrich, USA. The reference drugs used include cimetidine, omeprazole, ascorbic acid, and alpha-tocopherol. Analytical type reagents and chemicals utilized in this research were ordered from May \& Baker LTD, England. Double beam UV-Visible Spectrometer (PG Instruments Ltd,
T80+, S/N 151885-01-0094) was utilized in measuring the absorbance.

\section{Animals}

Male Albino rats $(180-190 \mathrm{~g})$, and Swiss albino mice $(18-20 \mathrm{~g})$ were used in the study. The animals were acquired from the Animal care house at the Physiology department of the College of Medicine, Lagos University Teaching Hospital, Idi araba campus, Lagos, Nigeria. They were harboured in a dirt free cage with the rats separated from the mice and preserved in a well ventilated room. They fed on standard pellet diet (Livestock Nigeria brand) and tap water was made available ad libitum. The animals were maintained under standard condition of $\left(23 \pm 1^{\circ}\right.$ C), on a light/day cycle for $12 \mathrm{~h}$ and the cage cleaned frequently. The study procedure was in compliance with the nationally accepted guidelines for laboratory animal use and care and consent was given by Health Research Ethics Committee (HREC), of the College of Medicine, University of Lagos, Nigeria, with approval number CMUL/HREC/07/17/212. The Guide for the Care and use of Laboratory Animal was followed for the research [7].

\section{Collection of plant material}

D. adscendens leaves and stems were gathered from Ibadan, Nigeria. The materials were authenticated by Mr. Adeleke at the Pharmacognosy department, University of Lagos, and a sample was kept at the herbarium of Pharmacognosy department, University of Lagos, Nigeria with the voucher number PCGH164. The samples were dried at ambient temperature and milled into a uniformly dried powder.

\section{Preparation of extracts}

Dried powdered leaf sample (200 g) was immersed in $1000 \mathrm{~mL}$ of $96 \%(\mathrm{w} / \mathrm{v})$ methanol for 3 days. The extract was sieved through Whatman filter paper no. $42(125 \mathrm{~mm})$ and the filtrates collected were dried using a rotary evaporator at $40{ }^{\circ} \mathrm{C}$. It was suitably labelled and kept in a cool place until use. The same process was replicated for the stem sample.

\section{Phytochemical screening}

The qualitative phytochemical examination of the extracts of $D$. adscendens stem and leaf was conducted by using standard methods $[8,9]$. The extracts were examined for the following phytochemicals; flavonoids, glycosides, 
alkaloids, tannins, and saponins using appropriate reagents.

\section{Determination of antioxidant activity}

\section{$D P P H$ radical scavenging activity}

The scavenging activity of $D$. adscendens extracts against 2, 2-diphenyl-1-picrylhydrazyl radical was ascertained by reading the UV absorbance at $517 \mathrm{~nm}$, as stated by the modified procedures of Amaeze et al, and Brand-Williams et al [10, 11]. Different concentrations of the extracts $(0.02,0.04,0.06,0.08$ and $0.1 \mathrm{mg} / \mathrm{mL})$ were prepared with methanol, using alphatocopherol, and ascorbic acid as standards. For each prepared solutions, $2 \mathrm{ml}$ was transferred into test tubes and added to it was $0.5 \mathrm{ml}$ of 1 $\mathrm{mM}$ 2, 2-diphenyl-1-picrylhydrazyl solution in methanol. The tests were done in triplicates. The prepared solution was agitated and allowed to rest for $15 \mathrm{~min}$ at ambient temperature, and the absorbance was measured spectrophotometrically at $517 \mathrm{~nm}$ [12]. DPPH inhibitory activity (D) was computed as in Eq 1. Reduction in absorbance measurement indicates the extent of antioxidant activity of the solutions.

$D(\%)=\left\{\left(A_{0}-A_{1}\right) / A_{0}\right\} 100$

where $A_{0}$ is blank absorbance, $A_{1}$ is test sample absorbance and $\mathrm{D}$ is the DPPH inhibitory activity.

\section{Total antioxidant assay (FRAP assay)}

An adapted method of Benzie and Strain [13] was assumed for the ferric reducing antioxidant power (FRAP) assay. The principle involved relies on the capability of the test sample to decrease the ferric tripyridyltriazine (Fe [III]TPTZ) complex to ferrous tripyridyltriazine ( $\mathrm{Fe}$ [II]-TPTZ) at low a pH. Fe [II]-TPTZ has an intense blue colour which was taken at $593 \mathrm{~nm}$. Newly prepared FRAP solution $(1.5 \mathrm{~mL})$, containing $25 \mathrm{~mL}$ of $300 \mathrm{mM}$ acetate buffer at $\mathrm{pH}$ $3.6,2.5 \mathrm{~mL}$ of $10 \mathrm{~mm} \mathrm{2,3,6-TPTZ} \mathrm{in} 40 \mathrm{mM} \mathrm{HCl}$, and $2.5 \mathrm{ml}$ of $20 \mathrm{mM}$ Iron(III)chloride hexahydrate $\left(\mathrm{FeCl}_{3} \cdot 6 \mathrm{H}_{2} \mathrm{O}\right)$ solution was transferred to $1 \mathrm{~mL}$ of the extracts and absorbance taken at $593 \mathrm{~nm}$ [14]. Calibration plot was linear between 50 - 300 $\mu \mathrm{M}$ and it was prepared with $\mathrm{FeSO}_{4} \cdot 7 \mathrm{H}_{2} \mathrm{O}$ solution. Results are indicated in $\mu \mathrm{M} \mathrm{Fe} \mathrm{(II)/g} \mathrm{dry}$ plant material and were juxtaposed with that of ascorbic acid.

\section{Total phenolic content}

The phenolic content of the extract of $D$. adscendens was determined on the authority of Folin and Ciocalteau method [15] with slight modifications. The calibration curve was derived by adding gallic acid in ethanol $(1 \mathrm{~mL}, 0.025$ $\mathrm{mg} / \mathrm{mL}$ ) to $5 \mathrm{ml}$ Folin-Ciocalteau reagent (on ten folds dilution) and $\mathrm{Na}_{2} \mathrm{CO}_{3}(4 \mathrm{~mL}, 0.7 \mathrm{M})$. Absorbance was determined at $765 \mathrm{~nm}$. One $\mathrm{ml}$ of the extracts in ethanol $(5 \mathrm{mg} / \mathrm{ml})$ was added to the reagent, mixed and after $2 \mathrm{~h}$ the absorbance was read to confirm the phenolic content. Each test was done in triplicate. The result was exhibited as gallic acid equivalent (GAE) $\mathrm{mg} / \mathrm{g}$, using the equation derived from the calibration curve: $y=11.523 x+0.678, R^{2}=0.999$.

\section{Total flavonoid content}

The flavonoid content was studied with the procedure of Miliauskas et al [16]. To $2 \mathrm{ml}$ of the extracts in methanol (concentrations of 0.1 and 1 $\mathrm{mg} / \mathrm{mL}$ ), was added $2 \mathrm{ml}$ of $2 \% \mathrm{AlCl}_{3}$ in ethanol and the absorbance was read at $420 \mathrm{~nm}$ after $1 \mathrm{~h}$ of incubation at room temperature. The concentrations of rutin prepared in methanol (0.01, 0.02, $0.04,0.08$ and $0.10 \mathrm{mg} / \mathrm{mL}$ ) were used to establish the calibration plot. Total flavonoid content was calculated as rutin equivalent $(R E)$ in $\mathrm{mg} / \mathrm{g}$ using the equation derived from the calibration curve: $y=0.5451 \mathrm{x}+$ $0.0203, R^{2}=0.9205$.

\section{Toxicity studies}

Acute toxicity study was conducted by using gradient doses of each extracts in albino mice. They were splitted into four groups, each of seven mice each, the stem extract were administered orally in graded doses $(5,000$, $10,000,15,000$ and $20,000 \mathrm{mg} / \mathrm{kg}$ body weight). They were observed at various time intervals (30 min, 1, 2, 3 and $4 \mathrm{~h}$ ) for toxic symptoms and mortality.

Sub-acute toxicity was conducted by a single administration of the dose to the animals with daily observation and weighing of the mice for one week [17].

\section{Anti-ulcer activity study}

Ulcer was established by administering ethanol, and the route of administration of prepared solutions was by oral. The adult male albino rats were made to abstain from food for $36 \mathrm{~h}$ prior to the administration of ethanol. The animals were split into seven groups, each made up of four rats except for the control group which contains three rats:

Group I: animals were administered distilled water only and this represents the control group 
Group II: received cimetidine $(5.7 \mathrm{mg} / \mathrm{kg})$ as reference drug

Group III: received Omeprazole $0.57 \mathrm{mg} / \mathrm{kg}$ ) as reference drug

Group IV: Received methanol extract (100 $\mathrm{mg} / \mathrm{kg}$ ) of $D$. adscendens leaf

Group V: Received methanol extract $(200 \mathrm{mg} / \mathrm{kg}$ ) of $D$. adscendens leaf

Group VI: Received methanol extract (100 $\mathrm{mg} / \mathrm{kg}$ ) of $D$. adscendens stem

Group VII: Received methanol extract (200 $\mathrm{mg} / \mathrm{kg}$ ) of $D$. adscendens stem.

After about $30 \mathrm{~min}$, all animals were orally given $1 \mathrm{ml}$ of ethanol and thereafter kept in a specially built cage to prevent coprophagia. They were afterwards decapitated after $1 \mathrm{~h}$ of administration; the stomach was incised along the greater curvature and cleansed in physiological saline solution to remove debris. It was laid flat and gastric mucosa lesions immediately traced on acetate paper using a magnifying lens. Ulcer protection (U) was calculated as in Eq 2.

$U(\%)=\{(U c-U t) / U c) 100$

where $U_{c}$ is the control ulcer index and $U_{t}$ is the ulcer index of disease tested control group [18].

\section{Statistical analysis}

The data are presented as mean \pm standard error of mean (SEM). Comparisons were done between the treated groups by two-way analysis of variance (ANOVA) using SPSS. The level of statistical significance was set at $p<0.05$.

\section{RESULTS}

Phytochemical evaluation of the $D$. adscendens stem and leaf unveiled the confirmation of flavonoids, glycosides, saponins, tannins, and alkaloids.

DPPH assay data showed inhibitory activity ranging from $3.17-91.37 \%$ for leaf extract, 2.87 $-61.65 \%$ for stem extract, $43.93-92.58 \%$ for alpha tocopherol, and $95.97-97.97 \%$ of ascorbic acid (Figure 1) with $\mathrm{IC}_{50}$ of 87.59, $108.87,28.52$ and $5.05 \mu \mathrm{g} / \mathrm{mL}$ respectively. The FRAP assay of the Desmodium adscendens stem was $1483 \mu \mathrm{M} \mathrm{Fe}^{2+} / \mathrm{g}, 1953 \mu \mathrm{M} \mathrm{Fe} e^{2+} / \mathrm{g}$ for the leaf extract, while the ascorbic acid had a value of $3463 \mu \mathrm{MFe}^{2+1} \mathrm{~g}$.
Total phenolic contents were derived from the regression equation of the calibration plot of gallic acid $\left(y=11.523 x+0.6775, R^{2}=0.998\right)$ and expressed as gallic acid equivalent (GAE). The phenolic content of the leaf and stem of $D$. adscendens were 10 and $24 \mathrm{mg} / \mathrm{g}$ of plant material, respectively. The correlation coefficient $\left(R^{2}\right)$ between the DPPH inhibition and total phenolic content were 0.997 and 0.986 for leaf and stem respectively. Total flavonoid content was calculated from the regression equation of the calibration plot of rutin $(\mathrm{y}=0.5451 \mathrm{x}+0.0203$, $\left.R^{2}=0.92\right)$ and expressed as rutin equivalent (RE). Total flavonoid contents were determined as 2.76 and $2.58 \mathrm{mg} / \mathrm{g}$ of powdered plant extract for leaf and stem of $D$. adscendens respectively. Acute toxicity studies on the stem extract showed the death of two mice at the highest dose of 20 $\mathrm{g} / \mathrm{kg}$, which accounts for $28.57 \%$ mortality, while no death was observed at lower doses. The subacute oral toxicity revealed death at 15 and 20 $\mathrm{g} / \mathrm{kg}$, which account for 14.29 and $42.84 \%$ of dead mice respectively.

Pre-treatment with cimetidine and omeprazole were discovered to inhibit the ethanol induced intestinal mucosal lesion in rats. The methanol extracts of $D$. adscendens leaf and stem revealed a dose-dependent antiulcer activity. The rats treated with extracts at 100 and $200 \mathrm{mg} / \mathrm{kg}$, doses respectively, showed significant $(p<0.05)$ reduction in the number of ulcer index. The results showed 14.27 and $15.18 \%$ ulceration inhibition at doses of 100 and $200 \mathrm{mg} / \mathrm{kg}$, respectively for $D$. adscendens leaf extract, while the $D$. adscendens stem extract showed 12.31 and $13.36 \%$ ulceration inhibition at doses of 100 and $200 \mathrm{mg} / \mathrm{kg}$ respectively. However, cimetidine showed ulceration inhibition of $5.53 \%$ at a dosage of $5.7 \mathrm{mg} / \mathrm{kg}$, while omeprazole showed ulceration inhibition of $8.26 \%$ at a dosage of $0.57 \mathrm{mg} / \mathrm{kg}$.

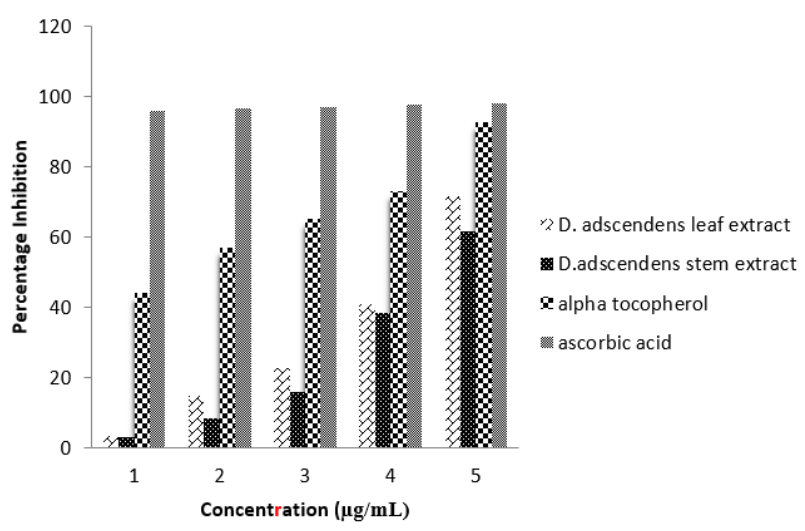

Figure 1: DPPH free radical scavenging activity of methanol leaf and stem extracts of $D$. adscendens as well as alpha-tocopherol and ascorbic acid 


\section{DISCUSSION}

Preliminary phytochemical evaluation confirmed the presence of flavonoids, glycosides, alkaloids, tannins, and saponins in extracts of the stem and leaf of $D$. adscendens. Phytochemical quantification showed the phenolic content of $D$. adscendens leaf and stem as $10 \mathrm{mg} \mathrm{GAE} / \mathrm{g}$ and $24 \mathrm{mg} \mathrm{GAE} / \mathrm{g}$ of plant material, respectively, while the flavonoid content was $2.76 \mathrm{mg} / \mathrm{g}$ and $2.54 \mathrm{mg} / \mathrm{g}$ for leaf and stem extracts respectively. This is similar to the results from the work of Konan et al [19] who found total phenolics (3.76 $\mathrm{mg} \mathrm{GAE} / \mathrm{g}$ ) and (2.15 mg GAE/g) for the leaf and stem; also 0.077 and $0.02 \%$ of flavonoids were found in the leaf and stem.

The scavenging property of $D$. adscendens stem and leaf extract may be ascribable to the phenolic compounds that can supply the necessary component as a radical scavenger. The $I C_{50}$ value for the leaf $(87.59 \mu \mathrm{g} / \mathrm{mL})$ was lower than the stems extract $(108.87 \mu \mathrm{g} / \mathrm{mL})$, which reflects a good demonstration of its antioxidant activity. While the research of Konan et al demonstrates that the ethyl acetate extracts of the leaf of $D$. adscendens has $I_{50} 260 \mu \mathrm{g} / \mathrm{mL}$ for radical scavenging property based on DPPH assay [19]. Free radicals are often generated as a result of biological reactions or from exogenous factors, its implication in the progression of some disease conditions is well established and has been published [20]. The antioxidant property of $D$. adscendens stem and leaf could be related to the high amount of flavonoid and phenolic compounds in this plant extract [21].

Ethanol-induced intestinal ulcer is a suitable model for exploring the gastroprotective effects of herbal drugs. The causes of peptic ulcer are still unknown in most cases; nevertheless, it has been recommended that it results from a variation between some destructive elements and the preservation of mucosal cohesion through the internal defense mechanisms. To restore this balance, different therapeutic agents like H2-blockers, proton pump inhibitors, and plant based substances have been used [22]. $D$. adscendens stem and leaf extracts used in this study to evaluate the anti-ulcerogenic in ethanol induced ulcers in rats showed a significant dose dependent ulceration inhibition activity at 100 and $200 \mathrm{mg} / \mathrm{kg}$ respectively. This could arise from a cytoprotective effect of the extracts through anti-oxidant effects. The anti-ulcer effect of $D$. adscendens stem and leaf could arise from two factors: reductions in gastric acid release and gastric cytoprotection. The remarkable increase in the anti-ulcer effect of $D$. adscendens leaf and stem extracts might be accredited to the confirmation of saponins, glycosides, tannins, and flavonoids compounds. Flavonoids are in the group of cytoprotective substance where its antiulcer efficacy has been studied [23]. Hence, the anti-ulcer activity of $D$. adscendens may be assigned to its flavonoids content.

It is well known that ethanol causes disorder in gastric secretion, destruction of the mucosa alters the permeability of the gastric membrane, gastric mucus depletion, and free radical production. This has been accredited to the release of free hydroperoxy and superoxide anion radicals produced during metabolism of ethanol. Free radicals derived from oxygen have been indicated in the mechanism of action of acute and chronic ulceration in the mucous membrane of the gastrointestinal tract [24]. Ethanol induction of gastric ulcer which causes the development of necrotic features of tissue lesion and haemorrhage, may arise from inactivity in gastric blood flow. The alcohol rapidly infiltrates the intestinal mucous membrane and causes destruction to the plasma and cell membrane, which leads to increased intracellular membrane permeability to sodium and water.

Furthermore, an enormous intracellular increase of calcium correlates with a vital pace in the development disease state of gastric mucosal lesion [22]. It is indicated that active phytochemical compounds would be able to stimulate mucus, bicarbonate and the prostaglandin secretion and, counteracts the distorting activity of reactive oxidants in the stomach and intestinal lumen [25]. Hence, this research recommends that the methanol extract of $D$. adscendens stem and leaf may be used to forestall gastric lesions. Thither is a demand to identify specific molecular species present in the extracts which are responsible for its gastroprotective effect, nevertheless, this would warrant further investigations.

\section{CONCLUSION}

The findings of this study indicate that methanol extracts of Desmodium adscendens stem and leaf are rich in phenolics and flavonoids, with high antioxidant activities, and also may offer a new gastroprotective treatment against ethanolinduced ulcers.

\section{DECLARATIONS}

\section{Acknowledgement}

The authors thank the technical staff of the Department of Pharmaceutical Chemistry, 
Faculty of Pharmacy, University of Lagos, Lagos, Nigeria for support.

\section{Conflict of interest}

No conflict of interest is associated with this work

\section{Contribution of authors}

We declare that this work was done by the authors named in this article and all liabilities pertaining to claims relating to the content of this article will be borne by the authors. Gloria A. Ayoola conceived and designed the study/ experiment. Oluwatosin O. Johnson and Samuel $O$. Eze collected and analysed the data. Oluwatosin O. Johnson and David K. Adeyemi wrote the manuscript. All authors have read and approved the manuscript for publication.

\section{REFERENCES}

1. Adjanohoun EJ, AkéAssi L, Chibon $P$, De Vecchy $H$, Duboze E, Eyme J, Gassita JN, Nguéma MG, Ollome $J B$, Posso $P$, Sita $P$. Contribution aux etudes ethnobotaniques et floristiques au Gabon. Agence de Coopération Culturelle Goudote E., Guinko S., Keita A., Koudogbo B., Le bras M., Mourambou I., MveMengonme et Technique (A. C. C. T.) Paris (France); 1984; $p 294$.

2. Rastogi S, Pandey MM, Rawat AKS. Pharmacognosy and Ethnopharmacology Division, National Botanical Research Institute, Rana Pratap Marg, Lucknow 226 001, India. J Ehnopharmacol 2011; 136(2): 283-296.

3. Muanda FN, Soulimani R, Dicko. A Study on biological activities and chemical composition of extracts from Desmodium adscendens leaves. J Nat Prod 2011a; 4: 100-107.

4. Addy ME. Several chromatographically distinct components from Desmodium adscendens inhibit smooth muscle contractions. Int J Crude Drug Res 1989; (27): 81-91.

5. Muanda FN, Bouayed J, Djilani A, Yao C, Soulimani R, Dicko. A chemical composition and, cellular evaluation of the antioxidant activity of Desmodium adscendens leaves. Evid Based Complement Alternat Med 2011; 2011: 1-9.

6. Francois C, Fare M, Baicchi C, Maixent JM. Safety of Desmodium adscendens extract on hepatocytes and renal cells; Protective effect against oxidative stress. $J$ Intercult Enthnopharmacol 2015; 4(1): 1-5.

7. Guide for the care and use of Laboratory animals, Committee for the update of the Guide for the Care and use of Laboratory Animals, Institute for Laboratory Animal Research 8th Ed, (2011).

8. Radia C, Mounira KA, Imen T, Akila B, Noreddine KC. Phytochemical analysis, antioxidant and antimicrobial activities of leaves and flowers ethyl acetate and n- butanol fractions from an Algerian endemic plant Calycotome spinosa (L.) J Pharmacogn Phytother 2017; 9(12): 185-196.

9. Trease GE, Evans WC. Pharmacognosy 13th edn. Bailliere Tindall, London, 1989; p. 176-180.

10. Amaeze OU, Ayoola GA, Sofidiya MO, Adepoju-Bello AA, Adesegun $A O$, Coker $H A B$. Evaluation of antioxidant activity of Tetracarpidim conophorum (Mull. Arg) Hutch \& Dalziel Leaves. Oxid Med Cell Longev 2011; 2011: 17.

11. Brand-Williams W, Cuvelier ME, Berset C. Use of a free radical method to evaluate antioxidant activity. Lebenson Wiss and Technol 1995; 28(1): 25-30.

12. El-Hajjaji F, Abdellaoui A, Taleb M, Hammouti B, Zarrouk A. Chemical composition, anticorrosion and antioxidant activity of clove (Syzygium aromaticum) oil. J Nat Prod 2017; 10: 45-57.

13. Benzie IFF, Strain JJ. The ferric reducing ability of plasma (FRAP) as a measure of antioxidant power: The FRAP assay. Anal Biochem 1996; 239(1): 70-76.

14. Osagie-Eweka SDE. Phytochemical analysis and comparative in-vitro antioxidant studies of aqueous, methanol and ethanol stem bark extract of Simarouba glauca DC. (Paradise tree). Afr J Plant Sci 2018; 12(1): 7-16.

15. Syama HP, Nisha $P$, Jayamurthy $P$. Antioxant activity, phenolic-flavonoid content and high performance liquid chromatography profiling of three different variant of Syzygium cumini seed: A comparative study. J Intercult Ehtnopharmacol 2017; 6(1): 107-114.

16. Miliauskas G, Venskutoninis R, Van-Beek TA. Screening of radical scavenging activity of some medicinal and aromatic plant extract. Food chem 2004; 85(2): 231-237.

17. Mutalik S, Paridhavi K, Rao CM, Udupa N. Antipyretic and analgesic effect of leaves of Solanum Melongena Linn in rodents. Indian J Pharmacol 2003; 35: 312-315.

18. Bhalke RD, Giri MA., Anarthe SJ, Pal SC. Antiulcer activity of ethanolic extract of leaves of Sesbania grandiflora (LINN). Int J Pharm Pharm Sci 2010; 2: 206208.

19. Konan KF, Mamyrbekova-Bekro JA, Bekro Yves-Alin. Quantification of total phenols and flavonoids of Desmodium adscendens (Sw.) DC. (Papillionaceae) and projection of their antioxidant capacity. J Appl Biosci 2012; 49: 3352-3362.

20. Uddin S, Ahmad S. Antioxidant protection against cancer and other human diseases. Compr Ther 1995; 21: 4145.

21. D'abrosca D, Pacifico S, Cefarelli G, Mastellone $C$, Fiorentino A. 'Limoncella' apple, an Italian apple cultivar: Phenolic and flavonoid contents and antioxidant activity. Food chem 2007; 104: 1333-1337.

22. Raju D, llango K, Chitra V, Ashish K. Evaluation of antiulcer activity of methanolic extract of Terminalia Chebula fruits in experimental rats. J Pharm Sci Res 2009; 1: 101-109.

23. Craciunescu O, Constantin D, Gaspar A, Toma L, Utoiu $E$, Moldovan L. Evaluation of antioxidant and 
Ayoola et al

cytoprotective activities of Arnica Montana L. and Artemisia absinthium L. ethanolic extracts. Chem Cen J 2012; 6: 97-108.

24. Savarino V, Mela GS, Celle G. Omeprazole in gastric and duodenal ulcers. Gut 1991; 32: 721 -724.
25. Mani S, Kumar KT, Puia Z, Samanta SK, Barik R, Dutta $A$, Gorain B. The gastroprotective role of Acanthus ilicifolius - A study to unravel the underlying mechanism of anti-ulcer activity. Sci Pharm 2012; 80: 701-717. 